\title{
From ISET to InDRE. I. Sanitary and Tropical Diseases Institute: Genesis and early years, 1934-1940.
}

\author{
Jorge Alejandro Ramírez-Hernández, ${ }^{1}$ María del Carmen Guzmán-Bracho ${ }^{2 *}$ and \\ José Alberto Díaz-Quiñonez ${ }^{2}$ \\ 'Universidad Nacional Autónoma de México, Faculty of Medicine; ${ }^{2}$ Instituto de Diagnóstico y Referencia Epidemiológicos. Ciudad de México, Mexico
}

\begin{abstract}
Lázaro Cárdenas government vision, and the process to create the Sanitary and Tropical Diseases Institute, which is considered strategic for public health, were consistent with the actions that were carried out: the Department of Public Sanitary asked the most relevant scientist of those days, Eliseo Ramírez, to design and follow-up the Institute's project. A commission of the Higher Education and Scientific Research Council reviewed and approved the project and conferred this institution its nature of research center with social and humanistic vocation since its foundation. Sanitary and Tropical Diseases Institute became the first post-revolutionary health institution that was born with well-remunerated job positions to conduct full-time research in Mexico, offering clinical services, teaching and supporting disease prevention and control campaigns. It was with no doubt a milestone in Mexican public health and crystalized the expectations of several generations of physicians and health researchers about having a high-level institution. It is the most significant public health institution of the country, with a new phase as Institute of Epidemiological Diagnosis and Reference. Without it, Mexican modern public health cannot be understood.
\end{abstract}

KEY WORDS: Sanitary and Tropical Diseases Institute. Institute of Epidemiological Diagnosis and Reference. History of medicine. Public health.

\section{Introduction}

The initial idea for the creation of an institute to investigate tropical diseases in Mexico can be found in Plutarco Elías Calles biographical background, who suffered from a tropical disease before being declared president. After the elections, he traveled to Europe, ${ }^{1}$ to Hamburg, to be treated for Pott's disease or tuberculous spondylitis. He conceived the project of an institute to study this type of ailments. During his presidency, the Public Sanitary Department building, currently the Ministry of Health, was constructed in front of Chapultepec (1926-1928), but the project of the institute remained pending.

Later, during Abelardo Rodríguez presidency, a proposal for the creation of a public health research center was received. Political events hindered its implementation, but
Gastón Melo, head of the Public Sanitary Department of, left it established in the corresponding chapter of the sixyear plan. ${ }^{2,3}$

The National Revolutionary Party, founded in 1929 by Calles, developed a government plan in 1933 and Lázaro Cárdenas' six-year plan was based on those initiatives. The official document of that plan, of December 1933, read "since Mexico is a country invaded by several tropical diseases, an institute will be stablished for the study of those ailments". ${ }^{4}$

Another proposal that reinforced the latter was that of the First National Congress of Rural Hygiene, held in Michoacán, and attended by Miguel E. Bustamante and Manuel Martínez Báez. One of the recommendations demanded for the Department of Public Health to expedite the installation of the Sanitary and Tropical Diseases Institute. ${ }^{5}$
Correspondence:

*María del Carmen Guzmán-Bracho

E-mail: cguzmanbracho@ hotmail.com
Date of reception: 13-03-2019

Date of acceptance: 22-03-2019

DOI: 10.24875/GMM.M19000276
Gac Med Mex. 2019;155:297-302

Contents available at PubMed www.gacetamedicademexico.com 
At the time the 1934-1940 Sexennial Plan was drafted, Mexico had a Public Sanitary Department in charge of campaigns against specific conditions: smallpox, malaria, rabies, onchocerciasis, tuberculosis, sexually transmitted diseases and malnutrition ${ }^{6,7}$

In the early 1930s, the Mexican population was less than 17 million inhabitants, $76 \%$ were rural areas' residents and more than $60 \%$ were younger than 30 years; life expectancy at birth reached only 33.9 years, 33.0 for men and 34.7 for women. Overall mortality was 8.6 per 100,000 population and preschool and childhood mortality rates were 36.0 and $131.6 .^{8}$ According to the groups of diseases used in those days, more than $40 \%$ of deaths throughout the national territory in the 1931-1940 period were due to infectious and parasitic diseases (Table 1).

In a breakdown of this information, pneumonia, diarrhea and congenital abnormalities were observed to be responsible for at least $70 \%$ of deaths. ${ }^{9}$ The main six causes of death reported for that year were infectious diseases: diarrhea and enteritis, pneumonia and influenza, fever and malarial cachexia, whooping cough, smallpox and measles. In general, among the first 20 causes of death, $14(70 \%)$ were of the infectious type. ${ }^{10}$ In this context of health of the Mexican population, the Sanitary and Tropical Diseases Institute (ISET - Instituto de Salubridad y Enfermedades Tropicales) was born.

The purpose of this work is to describe and analyze the emergence and early years, from 1934 to 1940, of the Institute through consultation of primary sources: 12 historical archives, newspaper and periodicals libraries and photographic archives located in Mexico City and one in Geneva, Switzerland, were visited. Finally, the fundamental processes that gave birth to the Institute were analyzed.

\section{Genesis and beginning of activities}

Based on the provisions of the Sexennial Plan, also referred to in the 1934 Sanitary Code of the Mexican United States: ${ }^{11}$

Art. 464. The Public Sanitary Department will also found Institutes of Hygiene, for the investigation of its own problems, and especially of tropical diseases.

To foster these and other research and teaching initiatives, the government of Lázaro Cárdenas, on October 25, 1935, decreed the creation of the National Council of Higher Education and Scientific Research (CNESIC - Consejo Nacional de Educación Superior e Investigación Científica). ${ }^{12}$ Its primary mission was
Table 1. Percentage distribution of the main causes of death in the years 1931 and $1940^{\circ}$

\begin{tabular}{|l|l|c|c|}
\hline & Chapter & 1931 & 1940 \\
\hline I & Infectious and parasitic diseases & 45.5 & 43.1 \\
\hline VIII & Diseases of the respiratory system & 17.4 & 20 \\
\hline XVI & Signs, symptoms and III-defined conditions & 11.6 & 7.4 \\
\hline IX & Diseases of the digestive system & 4.4 & 4.6 \\
\hline XVII & Trauma and poisoning & 4.3 & 5.1 \\
\hline & Total & 83.2 & 80.2 \\
\hline
\end{tabular}

to create, transform or suppress higher education establishments, as well as give rise and organize institutes aimed at practicing scientific research..$^{13}$ This way, ensuring its high technical and scientific level was intended.

Revista del Instituto de Salubridad y Enfermedades Tropicales ${ }^{14}$ first issue editorial mentioned the work of a commission to formulate the project for the Institute, which was integrated in 1935 by Miguel E. Bustamante, Gerardo Varela, Eliseo Ramírez and Manuel Martínez Báez.

Shortly after, the Public Sanitary Department, in charge of José Siurob, asked Eliseo Ramírez Ulloa to develop the project for the Sanitary and Tropical Diseases Institute, in addition to appointing him representative of the Public Sanitary Department before that Council. ${ }^{15}$ Eliseo Ramírez Ulloa was the most prominent medical scientist of those days ${ }^{16}$ and head of the Central Laboratory (created in 1929).

As a result of this work, on March 24, 1936, the "Project for Organization of the Institute of Sanitary and Tropical Diseases Institute" was officially submitted to the $\mathrm{CNESIC}^{17}$ and Ramírez informed the plenary of the Council during the April 16 session. ${ }^{18}$

The review of the project was in charge of a CNESIC commission integrated by Rafael Illescas Frisbie, Juan O'Gorman, Alonso M. Jaimes and Eliseo Ramírez Ulloa. ${ }^{19,20}$ After two months' work, the project was approved on June 27, 1936, according to the minutes of the CNESIC session. ${ }^{21}$ Eliseo Ramírez, as a representative of the Public Sanitary Department before the Council, answered to the observations about the project:

The Public Sanitary Department, I think, will have no prob-
lem, since the fundamentals of the project or the programs
have not been modified, and given that this is simply a matter
of drafting, it will agree.

The project was approved by the plenary at 14:00 hours and the corresponding documents were signed 
by Enrique Díaz de León and Enrique Arreguín, CNESIC president and secretary, respectively. ${ }^{22}$ With this decision, the ISET works set forth in the Sexennial Plan did continue. With the support of the ruling issued by the Council, ISET became the first institution in post-revolutionary Mexico that was born complete, with posts assigned for health research, as well as clinical spaces with hospitalization to serve the population, in addition to supporting health and teaching campaigns at the School of Public Health. All in an institutional environment with humanistic values ${ }^{23}$ :

Taking into account that continuous effort is an indispensable condition for scientific work be fruitful, the Council considers of utmost importance that researchers are granted a fair immovability and a decent remuneration,... and that they also need tranquility to devote themselves entirely, without restrictions, to the study of matters that the State entrusts to their intelligence and effort.

One week after the session, José Siurob was officially informed of the final approval of the Project for Organization and General Programs of the Sanitary and Tropical Diseases Institute, with reference to the introduced amendments. ${ }^{24}$

\section{Beginning of activities}

To understand the beginning of ISET activities, it is suggested that the Institute was prepared for its formal opening in 1938; in fact, the newspapers announced it since 1937.

The significance of the approved project motivated the dissemination of the news to the population, according to the official letter sent by the CNESIC to the newspapers of larger circulation in those days. Thus, El Universal informed on the decision on July 7 , 1936: 25

Finally, it will be founded...

The Sanitary and Tropical Diseases Institute will address the study of public health technical problems related to existing tropical diseases in the Mexican Republic and surrounding areas, and of those that due to their nature can be approached in an Institute of this type.

To fulfill its purpose, the Institute will proceed to develop and to systematize the works that are currently carried out without coordination at different units of the Department. It will undertake research works on topics currently under study and other new ones, mainly those concerning research and the study of ailments of probable or possible existence in our tropical zone. Complementarily, it will be dedicated to research on alimentary hygiene in rural centers; it will study poisonings produced by venomous animals and plants, and will serve as a teaching institution and consultation center.

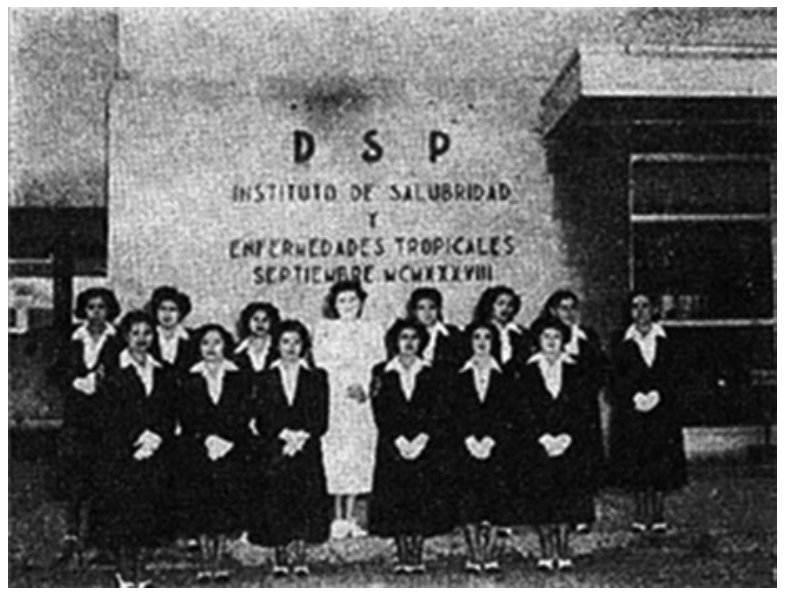

Figure 1. Inscription in metallic letters on the main facade of the Sanitary and Tropical Diseases Institute building, where the name of the Institute and its affiliation to the Public Sanitary Department are acknowledged, dated September 1938.

To perform its functions, it will have research laboratories, a clinical hospitalization section, library, museum, farm for laboratory animals and the necessary administrative sections. At its premises, it will house the Department's School of Public Health, which will be provided the necessary help for the best performance of its mission. The Public Health School will have the staff indicated by the Department and the relationships of this institution with the Institute will be established by special regulations that will be formulated by the Department.

Another document related to the beginning of activities prior to the formal opening is a photograph where the arrangement of the metallic letters on the main wall with the date "Septiembre MCMXXXVIII" can be observed (Figure 1). ${ }^{26}$

With a finished building in terms of construction ${ }^{27}$ and an authorized organization and operation project according to presidential provisions, it was necessary to lay efforts for the purchase of office and laboratory furniture, as well as equipment and supplies for the technical areas, and start the hiring of researchers. For this task, Suirob appointed Eliseo Ramírez again. The ISET was provided with high quality equipment and avant-garde instruments. Most of these resources were obtained through an oil barter with Germany, ${ }^{28}$ an unusual consequence that the nationalization of the oil industry left to Mexico, which had limited access to international markets for the sale of crude oil, but not so in the case of the Teutonic country, avid for oil due to the conflict it was preparing for. By 1982 , an infinity of German labels could still be found at the ISET on much of the equipment and reagents that were still on use in the laboratories (María del Carmen Guzmán-Bracho, personal reference). 
However, the oil nationalization, precipitated by the events in Europe (Austrian takeover by Hitler), ${ }^{29}$ became the presidential priority, which led to postponement of ISET formal opening until 1939.

\section{Eliseo Ramírez's activities}

The Institute started operating in early 1938, while the process of inviting researchers, receiving equipment and laboratory supplies and hiring of personal was taking place, as one of the researchers, Enrique Beltrán, narrates in his memoirs. ${ }^{28}$ The Revista de la Oficina Sanitaria Panamericana of that year, ${ }^{30}$ based on information from the Public Sanitary Department, informed on the event and the name of its director:

\footnotetext{
... which will address the study of technical problems related to tropical diseases existing in the Mexican Republic and surrounding areas, and to others that due to their nature can be approached in an establishment of this type. The Institute will start by developing and systematizing the work that currently is being carried out at different sections of the Public Sanitary Department. It will also undertake relevant research works, including alimentary hygiene at rural centers, poisonings produced by venomous animals and plants, and will equally serve as a teaching and consultation center... Eliseo Ramírez has been appointed director (Publ. Sanitary Dept. Inf.).
}

President Lázaro Cárdenas authorized the creation of special posts for the ISET laboratory heads with the scientific researcher A denomination, with a salary of $\$ 900.00$ per month, ${ }^{31}$ which constituted a high remuneration in those days.

As previously mentioned, Eliseo Ramírez participated since the beginning in the design the ISET project and its submission before the CNESIC, where he was also a representative of the Public Sanitary Department. After approval, he began to equip and hire the research staff for the Institute. In that period, presumably due to illness, he left these functions and returned in August 1940 as director. He died while still on duty on December 28, 1940 (Figure 2).

\section{Scientific production ${ }^{32}$}

The founding researchers were identified for incorporation to the Institute for their solid academic background and wide experience in the area of interest (Table 2).

Since its inception, the production of research manifested itself in the vast publication of articles by ISET researchers. Moreover, since the second year of operation, the Institute had its own journal, edited by the

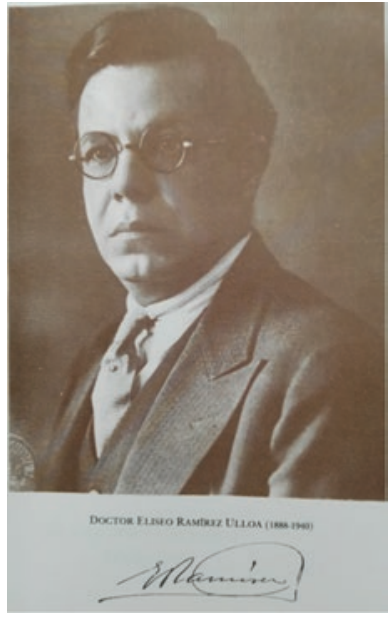

Figure 2. Eliseo Ramírez Ulloa. ${ }^{16}$

Directorate of Hygienic Education of the Public Sanitary Department, which...

... publishes the research works carried out by in-house staff and accepts contributions from national and foreign specialists.

The editorial board was initially integrated by Manuel Martínez Báez and Enrique Beltrán Castillo. The Revista del Instituto de Salubridad y Enfermedades Tropicales first issue, which appeared on the last quarter of 1939, published the initial works carried out by ISET researchers. This journal gathered the research production of different working groups of the Institute in 22 articles, where the institutional approach directed towards the main health problems of the country can be identified: 10 articles on parasitic diseases (eight on malaria and related protozoa and two on Chagas disease), five articles focused on the entomological subject (anophelines and other mosquitoes) and three reports of epidemiological data of interest such as population distributions, life tables and causes of death, which indicates the relevance of this journal to the Public Sanitary Department in those days. In the 1939-1946 period, the Institute researchers published 224 articles in Revista. The academic leadership of the institution, aimed at investigating and solving the main health problems can be identified: Luis Vargas published 37 articles, Luis Mazzotti 31, Beltrán 30, Bustamante 23, Varela 26, Zozaya 25, León 19 and González Ochoa, who joined the Institute in 1940, 13.

\section{Final comments}

This article has mentioned, regarding the Institute's project, two commissions. The first one, of 1935, was 
Table 2. Academic training of the Sanitary and Tropical Diseases Institute founding researchers

\begin{tabular}{|c|c|c|}
\hline Investigator & Area & Academic training \\
\hline Alberto P. León & Bacteriology and Immunology & Medical doctor (UNAM), master's Degree in Public Health (Harvard) \\
\hline Antonio González Ochoa & Mycology & $\begin{array}{l}\text { Medical doctor (UNAM), colonial physician (Paris), diploma in Medical } \\
\text { Mycology (Paris), specialization course (Germany) }\end{array}$ \\
\hline Efrén C. Del Pozo Rangel & Experimental therapeutics & Medical doctor (UNAM) \\
\hline Eliseo Ramírez Ulloa & Physiology and pharmacology & Medical doctor (UNAM), doctor of Sciences (UNAM) \\
\hline Enrique Beltrán Castillo & Protozoology & Professor in Natural Sciences (UNAM), PhD (Columbia, USA) \\
\hline Esther Luque Muñoz & Botany & Professor in Pharmacy (UNAM) \\
\hline Gerardo Varela Mariscal & Bacteriology & $\begin{array}{l}\text { Medical doctor (UNAM), postgraduate in Microbiology (Pasteur Institute, } \\
\text { H. Cochin } \\
\text { Paris), course in Public Health (Harvard) }\end{array}$ \\
\hline Luis Mazzotti Galindo & Helminthology & $\begin{array}{l}\text { Medical doctor (UNAM), course in Public Health (John Hopkins), diploma } \\
\text { in Tropical Medicine (Liverpool) }\end{array}$ \\
\hline Luis Vargas García Alonso & Entomology & $\begin{array}{l}\text { Medical doctor (UNAM), master in Biological Sciences (UNAM), course in } \\
\text { Public Health (John Hopkins) }\end{array}$ \\
\hline Manuel Martínez Báez & Pathological anatomy & $\begin{array}{l}\text { Medical doctor (Michoacán), malariologist physician (Paris) and } \\
\text { specialized courses in Italy, Spain and Germany }\end{array}$ \\
\hline Miguel E. Bustamante V. & Epidemiology & Medical doctor (UNAM), PhD (John Hopkins) \\
\hline Teófilo García Sancho & Chemistry & Chemical engineer (UNAM) and PhD (Kiel) \\
\hline
\end{tabular}

previously mentioned in the anonymous article in the editorial of the ISET journal first issue. ${ }^{14}$ In our research work, no primary reference was found in this regard.

On the other hand, the assignment by the Public Sanitary Department of Eliseo Ramírez as its representative at $\mathrm{CNESIC}^{15}$ (and who rejected the additional compensation offered by this Councili ${ }^{33}$ ) is documented, as well as his responsibility to obtain approval of the project and ISET's first organizational steps.

The other point to be clarified is the year the Institute started operating. There is plenty of evidence that, since 1938, the Public Sanitary Department reported, through Boletín de la Oficina Sanitaria Panamericana, the beginning of ISET's works and provided the director's name, Eliseo Ramírez, who had been appointed to design and ensure CNESIC's approval and subsequently the task of organizing, equipping and hiring researchers, as accurately described in Enrique Beltrán's testimony.

In addition to its scientific nature, it is important to make emphasis on ISET's humanistic nature. As examples, we found the works of Miguel E. Bustamante on the history of public health, philosophical essays by Eliseo Ramírez and works on tropical diseases' cultural aspects by Martínez Báez.
Without a doubt, the ISET was a watershed in the country's public health, ${ }^{34}$ since it crystallized the expectations of several generations of doctors and health researchers for having a high-level institution. At its new stage, as the Institute of Epidemiological Diagnosis and Reference (InDRE - Instituto Nacional de Diagnóstico y Referencia Epidemiológicos), it is the most significant public health institution of the country; without it, Mexico's modern public health cannot be understood.

\section{Acknowledgements}

To the authorities and personnel of the Historical Archive of the Ministry of Health. To PhD in History Andrés Ortiz Morales, deputy director of the Historical Archive of the National Polytechnic Institute.

\section{References}

1. Valenzuela GJ. El viaje de Plutarco Elías Calles como presidente electo por Europa y Estados Unidos. Rev Mex Sociol.1995;57:191-210.

2. Fondo CNESIC. C1E20F23. México: Archivo General de la Nación; 2018.

3. Melo G. Tercer director de la Escuela de Salubridad, 1926-1928. Bol Salubridad Mex. 1933;4:1-2.

4. Cárdenas-Del Río L. PNR: plan sexenal 1934-1940. México: Partido Nacional Revolucionario; 1933.

5. Oikión-Solano V. Primer Congreso Nacional de Higiene Rural celebrado en Morelia, del 3 al 12 de noviembre de 1935. Relaciones (COLMICH). 1993:14:273-303. 
6. Rodríguez ME. Aspectos médicos-sanitaristas en México (1934-1940). Gac Med Mex. 2017;153:609-612.

7. Viesca-Treviño C. Campañas contra enfermedades durante el cardenismo. Gac Med Mex. 2017:153:613-616.

8. Kumate J. La salud de los mexicanos. 1929-2000. México: El Colegio Nacional; 2010.

9. Estadísticas históricas de México. Tomo I. México: Instituto Nacional de Estadística, Geografía e Informática; 1994.

10. Compendio histórico. Estadísticas vitales 1893-1993. México: Secretaría de Salud; 2004

11. Código Sanitario de los Estados Unidos Mexicanos. Diario Oficial de la Federación 1934 Ago 31. p. 1164-1200.

12. Decreto que crea el Consejo Nacional de la Educación Superior y la Investigación Científica. México: Diario Oficial de la Federación; 1935 Oct 30. p. 1078-1079.

13. Archivo General de la Nación. Fondo CNESIC. C1E9F4. México: Archivo General de la Nación; 2018.

14. Anónimo. El Instituto de Salubridad y Enfermedades Tropicales. Revista del Instituto de Salubridad y Enfermedades Tropicales. 1939:1:3-35.

15. Fondo CNESIC. C21E16. México: Archivo General de la Nación; 2018.

16. Kumate J. Semblanza del Dr. Eliseo Ramírez Ulloa. En: Eliseo Ramírez Ulloa. Obras Completas. Tomo II. Investigación Médica. México: El Colegio Nacional; 1988.

17. Fondo CNESIC. C2E16F3. México: Archivo General de la Nación; 2018.

18. Fondo CNESIC. C1E20F14. México: Archivo General de la Nación; 2018.

19. Fondo CNESIC. C1E20F30. México: Archivo General de la Nación; 2018.
20. Fondo CNESIC. C1E20F33. México: Archivo General de la Nación; 2018.

21. Fondo CNESIC C1E20F59. México: Archivo General de la Nación; 2018.

22. Fondo CNESIC. C1E20F66. México: Archivo General de la Nación; 2018.

23. Fondo CNESIC. C2E16F86. México: Archivo General de la Nación; 2018.

24. Fondo CNESIC. C2E16F76. México: Archivo General de la Nación; 2018.

25. Instituto de Salubridad y Enfermedades Tropicales. Al fin se fundará. El Universal 1936 Jul 7. Primera plana.

26. Archivo Histórico de la Secretaría de Salud. Anuario de la Escuela de Salubridad e Higiene. México: Secretaría de Salubridad y Asistencia; 1952.

27. Andreu-Almazán L. La sanidad en México. Bol Oficina Sanitaria Panamericana. 1939;18:617-621.

28. Beltrán E. Medio siglo de recuerdos de un biólogo mexicano. México: Sociedad Mexicana de Historia Natural; 1977.

29. Cárdenas-Del Río L. Obras: Apuntes 1913/1940. Tomo I. México: Universidad Nacional Autónoma de México; 1972.

30. Boletín de la Oficina Sanitaria Panamericana. México: Oficina Sanitaria Panamericana/Instituto Mexicano de Investigación; 1938.

31. Fondo CNESIC. C20E5. México: Archivo General de la Nación; 2018.

32. Colección de la Revista del Instituto de Salubridad y Enfermedades Tropicales del Instituto de Diagnóstico y Referencia Epidemiológicos. México: Instituto de Diagnóstico y Referencia Epidemiológicos.

33. Fondo CNESIC. C7E16. México: Archivo General de la Nación; 2018.

34. Santos-Preciado JI, Franco-Paredes C. Enfermedades tropicales del rezago: a 72 años del establecimiento del Instituto de Salubridad y Enfermedades Tropicales en México. Bol Med Hosp Infant Mex. 2011; 68:83-85. 